ANNA WAWRZONEK

ORCID 0000-0003-0046-8212

Uniwersytet im. Adama Mickiewicza

$w$ Poznaniu

\title{
KOMPETENCYJNY ROLLERCOASTER - RODZINA, EDUKACJA, PRACA I (NIE)RELACYJNY WYMIAR TYCH PRZESTRZENI
}

\begin{abstract}
AвSTRACT. Wawrzonek Anna, Kompetencyjny rollercoaster - rodzina, edukacja, praca i (nie)relacyjny wymiar tych przestrzeni [Competency Roller Coaster - Family, Education, Work and (Non-)Relational Dimension of These Areas ]. Studia Edukacyjne nr 54, 2019, Poznań 2019, pp. 83-101. Adam Mickiewicz University Press. ISSN 1233-6688. DOI: 10.14746/se.2019.54.6

The main goal of the article is to indicate a significant issue of the shift of roles, competencies and functions we currently notice in various life areas as well as to stimulate reflection on reversing or at least redefining missions of institutions which prepare, or should prepare, for these roles. The insights I want to share are the result of literature studies as well as teaching experiences gained from the academic and school environment. I treat the title competency roller coaster as a metaphor for changes I observe being part of the world of science, education and work.
\end{abstract}

Key words: family, school, university, employer, change

Ludzkość staje w obliczu niespotykanych rewolucji, większość obowiązujących narracji upada, a ich miejsce próbują zająć nowoczesne technologie, które wyznaczają kierunki i kształt nowych narracji. Jak pisze Ewa Solarczyk-Ambrozik:

wyzwaniem stają się złożoność, zmiana, ale i szanse, możliwości oraz trudności. W zmieniającym się świecie rośnie znaczenie zdolności adaptacyjnej jednostki do zmian, odnajdywania się w sytuacjach tranzycji, konfrontacji z niepewnością w myśleniu i działaniu ${ }^{1}$.

${ }^{1}$ E. Solarczyk-Ambrozik, Transformacja pracy i zatrudnienia a kariera zawodowa. Perspektywa jednostkowa i organizacyjna, [w:] Uczenie się przez całe życie. Rozwój - kariera - praca, red. E. Solarczyk-Ambrozik, M. Barańska, Poznań 2018, s. 19. 
Wyzwaniem staje się też nowy porządek zależności, jaki obserwujemy w różnych przestrzeniach życia, w których funkcjonujemy.

Główną intencją niniejszego artykułu jest wskazanie na istotny, w moim odczuciu, problem zamiany/przesunięcia ról, kompetencji i funkcji, jakie pełnimy współcześnie $w$ różnych przestrzeniach życiowych oraz wzbudzenie refleksji dotyczącej odwrócenia albo przynajmniej redefiniowania misji instytucji, które do tych ról przygotowują bądź powinni przygotowywać. Spostrzeżenia, którymi pragnę się podzielić są wynikiem studiów literaturowych, ale też doświadczeń dydaktycznych wyniesionych ze środowiska akademickiego i szkolnego. Tytułowy kompetencyjny rollercoaster traktuję jako metaforę obserwowanych przemian, będąc częścią świata nauki, edukacji i pracy.

Kierując się potrzebą zgłębiania zainteresowań badawczych związanych z funkcjonowaniem rynku pracy, przyglądam się uważnie przemianom na nim zachodzącym: relacjom, jakie zachodzą między pracownikiem a pracodawcą, współpracownikami (prezentującymi różne pokolenia na rynku pracy), ale również jakości, kondycji procesu kształcenia i uczenia, zarówno na poziomie edukacji akademickiej (z perspektywy pracownika naukowo-dydaktycznego) oraz na poziomie edukacji szkolnej (z perspektywy nauczyciela i rodzica). Analizując zachowania młodych na rynku pracy w starciu z zawodową rzeczywistością, wyraźnie widzę związek między sposobem zachowania młodych osób na rynku pracy a edukacją szkolną i akademicką, a dokładniej - sposobem prowadzenia tej edukacji i jej wpływem na „kształt” przyszłych pracowników. Oczywiście można założyć, że wskazany związek jest naturalny i stanowi konsekwencję założonych wcześniej celów, jednak warto zauważyć, że działania podejmowane przez wskazane instytucje często mijają się z tymi, które pierwotnie zakładano. Obserwując przestrzenie, w których funkcjonuje, wychowuje, rozwija i uczy się człowiek, można odnieść wrażenie, iż każda z tych przestrzeni realizuje głównie wyznaczone sobie cele, w oderwaniu od innych przestrzeni i bez wyraźnych relacji do nich. Instytucje realizujące swoje zadania zdają się traktować podmioty korzystające ze świadczonych przez nie usług jako byty, funkcjonujące w sfragmentaryzowanych wycinakach rzeczywistości, które powinny realizować różne, niepowiązane ze sobą role, w odrębnych „światach" i przestrzeniach życiowych. Jak pisze Mieczysław Malewski:

zmienność i płynność ról społecznych „rozluźnia” systemowy charakter społeczeństwa i osłabia jego presję, otwierając przed ludźmi przestrzenie dla rozwoju i ekspansji „ja podmiotowego". Życie przestaje być postrzegane w kategoriach społecznych powinności człowieka, a staje się zespołem szans na podmiotowość i emancypację zlokalizowanych w różnych przestrzeniach społeczeństwa².

${ }^{2}$ M. Malewski, Od nauczania do uczenia się. O paradygmatycznej zmianie w andragogice, Wrocław 2010, s. 67. 
Pytanie tylko, czy poszczególne jednostki potrafią wskazane szanse wykorzystać albo przynajmniej je dostrzec? I czy powinno się podejmować działania, które stworzą optymalne warunki do ich wykorzystania?

Przestrzeniami, na które chciałabym zwrócić największą uwagę są: rodzina, instytucje edukacyjne, ze szczególnym uwzględnieniem szkoły oraz uczelni, i wreszcie praca. Wszystkie wskazane przestrzenie mają charakter rozwojowy i edukacyjny, powinny być miejscami nabywania, rozwijania różnorodnych umiejętności oraz zdobywania "sprawności” niezbędnych do bycia "kompetentnym dorosłym”, charakteryzującym się zintegrowaną tożsamością, doskonale funkcjonującym na różnych płaszczyznach życia, w zdrowych relacjach z innymi i do różnych miejsc oraz przestrzeni.

Pierwszą z prezentowanych przestrzeni, która stanowi fundament, podbudowę kolejnych jest rodzina. Uwzględniając przemiany w funkcjonowaniu współczesnej rodziny oraz podejmowany temat, warto przyjrzeć się klasyfikacji stylów wychowania prezentowanym w literaturze przedmiotu. Najczęściej wyróżnia się styl autokratyczny, demokratyczny i liberalny, dodatkowo w obrębie stylu liberalnego można wskazać liberalny kochający i niekochający. W opisie wyróżnionych rodzajów stylów przywołuje się zazwyczaj preferencje w stosowaniu systemu kar i nagród, uzgadnianie i porozumiewanie się z dzieckiem, dominację rodzica, wprowadzanie zasad i zainteresowanie rodzica dzieckiem ${ }^{3}$. Jak podkreśla Danuta Opozda, żaden z nich w praktyce nie występuje $\mathrm{w}$ "czystej formie", ale przeważające zachowania wychowawcze rodzica można w przybliżeniu podporządkować jednemu z nich. Z kolei, zmienność stylu wychowania w najbardziej istotny sposób wyraża się w dynamice preferencji zachowań wychowawczych rodziców i sposobie wychowania dziecka w rodzinie. Współcześnie wyraźnie obserwujemy ewolucję $\mathrm{w}$ stylach wychowania rodziny. Polega ona w głównej mierze na narastaniu stylu obojętnego (niezaangażowanego, niedbałego) i permisywnego (przyzwalającego, pobłażliwego, naiwnego $)^{4}$. Warto podkreślić, iż obserwowane tendencje mają dosyć ekspansywny charakter i ogólnoświatowy wymiar. Abstrahując od bogatej literatury dotyczącej znaczenia rodziny w życiu jednostki, chciałabym zwrócić uwagę na nowe role podejmowane przez współczesnych rodziców oraz związane z tym niebezpieczeństwa dla budowania spójnej tożsamości młodych osób. Od lat obserwujemy zwiększoną dostępność poradników na temat wychowania, które prześcigają się w promowaniu "nowoczesnych modeli wychowania" i tym samym skłaniają rodziców do „eksperymentowania” z własnymi dziećmi w tym obszarze. Odnaleźć moż-

${ }^{3}$ D. Opozda, Stałość i zmienność stylu wychowania w rodzinie w teorii i praktyce edukacyjnej, [w:] Wspótczesna rodzina w kontekstach społecznych i kulturowych, red. E. Jurczyk-Romanowska, M. Piwowarczyk, Wychowanie w rodzinie, t. XIII, Wrocław 2016, s. 185.

${ }^{4}$ Wspótczesna rodzina w kontekstach społecznych $i$ kulturowych, s. 186-88. 
na modele promujące skrajną dyscyplinę, stosowaną przez tak zwane „matki tygrysice", jak i te zachęcające do zaangażowanego rodzicielstwa w postaci tak zwanych "helikopterowych rodziców", którzy krążą nad dziećmi o każdej porze dnia i nocy oraz modele nadopiekuńczego rodzicielstwa, określane mianem "rodziców kosiarek". Rodzice helikopterowi znajdują swoim potomkom mnóstwo zajęć dodatkowych, mających zagwarantować im sukces w przyszłości. Precyzyjnie organizują dzieciom czas, skrzętnie wypełniając grafiki tak, aby nie zmarnować żadnej chwili. Rodzice helikopterowi zawsze są w pobliżu i zawsze pomogą, choć często nie mają na to sił. Do niedawna właśnie ten model wychowania był najczęściej promowany wśród współczesnych rodziców, często obserwowany w dużych miastach, gdzie oferta edukacyjna zajęć dodatkowych, prywatnych szkół i przedszkoli jest naprawdę imponująca. Jednak, od jakiegoś czasu obserwujemy nowy trend wychowawczy - rodziców "kosiarek”, którzy "koszą i wyrównują wszystko, co znajduje się na ścieżce życia ich dzieci" ${ }^{5}$, izolując je tym samym od jakichkolwiek trudności. Oczywiście, uzasadnione wydaje się takie zachowanie rodziców na etapie wieku niemowlęcego dzieci, niestety zaobserwowana praktyka staje się normą dla coraz większej rzeszy rodziców dzieci wczesnoszkolnych i starszych. Stosowanie permisywnego, zbyt liberalnego stylu wychowania wprowadza ryzyko wystąpienia tytułowej „wywrotki kompetencyjnej” - umiejętności, które powinny być rozwijane u dzieci od najwcześniejszych lat, czyli samodzielność, odpowiedzialność, radzenie sobie z trudnościami i z przegraną są przechwytywane przez rodziców. W rezultacie, dzieci pozbawione są możliwości ich "trenowania” i rozwijania, a może nawet wykształcenia. Ratowanie dzieci w każdej kłopotliwej sytuacji i wyręczanie ich nie sprzyja rozwijaniu samodzielności, wręcz odwrotnie - utrwala przekonanie, iż nie jest ona potrzebna, wzmacnia $\mathrm{w}$ dzieciach potrzebę zależności od rodziców, którzy zawsze przyjdą z pomocą, wybiorą i zastosują odpowiednie rozwiązanie. Takim postępowaniem dajemy młodym osobom nie tylko przyzwolenie na brak odpowiedzialności za siebie, gdyż wchodzimy w rolę „czarodziejskiej różdżki", która odczaruje każdą potencjalną porażkę, ale przede wszystkim pozbawiamy je poczucia sprawstwa i wbrew intencjom rodziców, działających „dla dobra dziecka”, również podmiotowości. Zdecydowanie efektywniejszą drogą do osiągania dorosłości będzie uczenie dzieci kreatywnego podejścia do problemu, wytrwałości, elastyczności i samokontroli. Bardziej przyszłościowy wydaje się nieco zmodyfikowany wymiar pomocy, oparty na wspieraniu a nie wyręczaniu, wzbogacony o atmosferę sprzyjającą nowym wyzwa-

\footnotetext{
${ }^{5}$ A. Ślusarczyk, Helikopterowi rodzice to już przeszłość. Nadchodza rodzice kosiarki. Poznaj nowy trend $w$ rodzicielstwie, https://www.babyboom.pl/uczen/wychowanie/helikopterowi-rodzice-to-juz-przeszlosc-nadchodza-rodzice-kosiarki-poznaj-kolejny-trend-w-rodzicielstwie [data dostępu: 30.05.2019].
} 
niom, które staną się motywacją do podejmowania kolejnych samodzielnych prób ${ }^{6}$. Kluczową kwestią w zdobywaniu nowych kompetencji w procesie uczenia się jest stworzenie warunków do tego, aby zdobyta umiejętność była wynikiem starań samego dziecka, a nie rodzica bądź nauczyciela. Niestety, promowane modele rodzicielstwa wywierają ogromną presję na rodzicach. Wychowywanie dziecka stało się czymś w rodzaju uprawiania sportu wyczynowego, w którym każdy chce zdobyć jak najwyższą lokatę ${ }^{7}$ W rezultacie proces wychowawczy sprowadza się do realizacji "projektu dziecko”, do „hodowli” młodego człowieka, który osiąga coraz lepsze wskaźniki i parametry, którymi rodzice często przechwalają się wśród znajomych czy rodziny. Niestety, wysokie wskaźniki z czasem tracą swoją magiczną moc. Konfrontacja z rzeczywistością, inną niż ta jaką kreują rodzice, następuje często już na etapie edukacji szkolnej albo najpóźniej na rynku pracy, co często skutkuje zachowaniami depresyjnymi, a czasami agresją młodych.

Kolejną przestrzenią, w której odnajduję odwrócony/zaburzony podział ról jest szkoła, będąca środowiskiem wielu paradoksów. Odwrócenie ról dotyczy zarówno uczniów, jak i nauczycieli jako podmiotów funkcjonujących w środowisku szkolnym oraz rodziców, którzy coraz częściej przejmują obowiązki, do niedawna przypisane głównie szkole. Jak pisze Marzena Żylińska, współczesny model szkoły mocno ogranicza aktywność uczniów, sprowadzając ich do odbiorców wiedzy, promując transmisyjny model nauczania ${ }^{8}$. Cytowana autorka przypomina, iż szkoły w obecnej formule powstały na przełomie XVIII i XIX wieku, i były dostosowane do ówczesnych uwarunkowań oraz oczekiwań ${ }^{9}$. Gwarantem rozwoju na miarę XXI wieku jest autonomia i innowacyjność; XIX-wieczny układ wertykalny dominujący w polskiej szkole, powinien, zdaniem M. Żylińskiej, zostać zastąpiony układem horyzontalnym. Proponowany układ charakteryzuje się odejściem od hierarchicznego zarządzania i zastąpienie go modelem opartym na współpracy i wymianie, co zdaniem autorki oznacza, iż posłuszeństwo i dyscyplina powinny wreszcie przestać odgrywać kluczową rolę ${ }^{10}$. Niestety, polska szkoła realizująca wizje programowe kolejnych rządów i przygotowująca do różnych testów, egzaminów, które wymagają jedynie odtwarzania wiedzy albo raczej wykorzystania zdobytych informacji, zdaje się jedynie pogłębiać przepaść między pruskim systemem edukacyjnym a nowoczesną edukacją, wykorzystującą kreatywność uczniów. Domeną polskiej szkoły są przeładowane programy i przestarzałe metody na-

${ }^{6}$ A. Wawrzonek, Sukces i jego implikacje dla ksztattowania tożsamości młodego człowieka, [w:] Uczenie się przez całe życie, s. 111-112.

7 C. Honore, Pod presja. Dajmy dzieciom święty spokój, Warszawa 2008.

${ }^{8}$ M. Żylińska, Neurodydaktyka. Nauczanie i uczenie się przyjazne mózgowi, Toruń 2013, s. 87.

9 Tamże, s. 227.

${ }^{10}$ Tamże, s. 231. 
uczania, w których koncentrujemy się na przekazywaniu ogólnodostępnych informacji i zabijaniu wrodzonych skłonności dzieci, takich jak ciekawość, kreatywność, czy kooperacja. Naturalna skłonność dzieci do kooperacji, w postaci prób wspólnego rozwiązywania zadań, jest w szkole najczęściej potępiana i nazywana oszustwem. W większości polskich szkół trzeba funkcjonować według ściśle określonych zasad, pracować samodzielnie, rozwiązywać zadania według klucza. Tymczasem, pracodawcy wysyłają młodych pracowników na szkolenia, żeby odzyskać, odbudować to, co szkoła zniszczyła, czyli kreatywność, pomysłowość i umiejętność pracy w grupie. Jeśli nauka w szkole ma przygotować do efektywnego funkcjonowania w dorosłym świecie, to uczniowie nie mogą bezmyślnie uczyć się na pamięć faktów i regułek, ale jak pisze M. Żylińska operując faktami, muszą samodzielnie odkrywać reguły i zasady. Mechaniczne wykonywanie zadań, wypełnianie kolejnych luk w zeszytach ćwiczeń nie angażuje uczniów emocjonalnie i nie sprawia im żadnej przyjemności, tym samym nie inicjuje procesu efektywnej nauki. Eksperci zajmujący się pedagogiką twierdzą, iż szkoły powinny przestawić się na uczenie „czterech K - krytycznego myślenia, komunikacji, kooperacji i kreatywności”, kłaść mniejszy nacisk na umiejętności techniczne, a silniej akcentować uniwersalne umiejętności życiowe. Zdaniem Yuval Nah Harari, najważniejsza z nich będzie zdolność radzenia sobie ze zmianą, uczenia się nowych rzeczy i zachowania równowagi psychicznej w nieznanych sytuacjach. Cytowany autor twierdzi, iż do nadążania za tempem świata do 2050 roku trzeba będzie nie tylko tworzyć nowe pomysły i produkty, lecz także, a może przede wszystkim, raz po raz na nowo tworzyć samego siebie ${ }^{11}$. Niestety, rozwiązania stosowane w polskiej szkole nie przewidują tego typu działań. Wręcz przeciwnie, rezultatem transmisyjnego modelu edukacji jest konieczność nadrabiania braków w domu. Uczniowie przychodząc do domów najczęściej przekazują rodzicom informację „nic nie rozumiem” i rusza machina wyrównywania braków wyniesionych ze szkoły. W rezultacie, rola szkoły sprowadza się do roli „przechowalni” dla dzieci, świetlicy, w której te, nudząc się, „wysiadują” kolejne godziny lekcyjne, po których biegną do drugiej szkoły w domu. Po raz kolejny możemy zauważyć mechanizm odwrócenia ról. Nauczyciel zamiast uczyć, co najwyżej przekazuje informacje, „realizuje” program, który często bywa przeładowany. Brakuje czasu na tłumaczenie i dyskusję, na przekazywanie wiedzy, zdobywanie nowych umiejętności, nie wspominając w ogóle o aspekcie wychowawczym edukacji szkolnej. W XXI wieku rolą szkoły i nauczycieli nie powinno być przekazywanie uczniom coraz większej ilości informacji, ale rozwijanie zdolności ich rozumienia, odróżniania tego co ważne od tego co nie, a przede wszystkim zdolności integrowania tych informacji w spójną całość ${ }^{12}$. Ważnym elementem

${ }^{11}$ Y.N. Harari, 21 lekcji na XXI wiek, Warszawa 2011, s. 335.

12 Tamże, s. 334. 
edukacji szkolnej powinien być także aspekt socjalizacyjny, wychowawczy, o którym praktycznie się zapomina. Nagminne staje się wykorzystywanie lekcji wychowawczych do nadrabiania zaległości z innych przedmiotów. Dodatkowo warto podkreślić, iż coraz mniej nauczycieli jest przygotowanych do pełnienia roli wychowawcy i rzadko z wyboru podejmują się tej misji. Podobnie jak w przypadku edukacji dorosłych, o czym pisze M. Malewski, „technologicznie zorientowana, instrumentalna $\mathrm{w}$ swym charakterze edukacja instrumentalizuje także nauczyciela"13, który w pewnym sensie staje się niewolnikiem programu, ocen, punktów i dzienników elektronicznych. Współcześni nauczyciele nie mają większego wpływu na organizację procesu edukacyjnego, a ich rola sprowadza się najczęściej do realizatorów zadań przygotowanych dla nich przez kolejnych ministrów, kuratorów i dyrektorów. Nie mają też przestrzeni do wymiany swoich spostrzeżeń, zastrzeżeń i pomysłów, czego najlepszym odzwierciedleniem były strajki nauczycielskie w 2019 roku, będące nie tylko wyrazem/krzykiem totalnej bezradności nauczycieli, ale także zwierciadłem problemów, z którymi musi się mierzyć polska szkoła, a przede wszystkim polski nauczyciel. Jak pisze Mikołaj Herbst, przechodzenie od modelu szkoły tradycyjnej, dokonującej transferu wiedzy, do szkoły stymulującej rozwój wymaga od nauczycieli bardzo szerokich kompetencji ${ }^{14}$, a to wymaga nie tylko automotywacji nauczycieli, ale przede wszystkim przygotowania systemu wsparcia oraz podjęcia wysiłków ukierunkowanych na odbudowanie autorytetu profesji nauczycielskiej. Oczywiście, w skali pojedynczych szkół można zaobserwować śmiałe projekty, realizowane przez dyrektorów i nauczycieli, powstają ruchy na rzecz nowoczesnej szkoły, na przykład Budząca Się Szkoła, ale by przeprowadzić zasadniczą, globalną zmianę potrzebni są liczni wykonawcy, nie wystarczy nauczycielska elita ${ }^{15}$. Efektem źle zorganizowanej/pomyślanej szkoły jest zaburzony układ ról pełnionych w rodzinie. Konsekwencją przeładowanych programów szkolnych, nieadekwatnych metod uczenia są dodatkowe zadania, które musi realizować rodzic w domu. Coraz częściej obserwujemy sytuacje, w których rodzice zamiast pracować nad umacnianiem więzi rodzinnych, spędzać czas z dziećmi na zabawie, angażują się w proces edukacji, przejmują rolę nauczyciela, co nie tylko obciąża ich czasowo, ale przede wszystkim psychicznie/emocjonalnie. Dodatkowo zaburza, żeby nie powiedzieć zabija, relacje rodzinne, nadaje nowy kształt przestrzeni, jaką jest rodzina. W domu zaangażowanych rodziców wszystko koncentruje się na szkole, zamiast na rodzinie. Uczeń zamiast pełnić w domu rolę dziecka, brata/

${ }_{13}$ M. Malewski, Od nauczania do uczenia się. O paradygmatycznej zmianie w andragogice, Wrocław 2010.

${ }^{14}$ M. Herbst, Reformowanie edukacji, [w:] Młodzi 2018, Warszawa 2019, s. 221, http://mlodzi2018.pl/files/raport14.pdf [data dostępu: 24.05.2019].

15 Tamże. 
siostry czy kolegi na podwórku, boisku i rozwijać swoje kompetencje społeczne, pełni rolę "zakładnika" chorego systemu edukacyjnego, wysiadując w domu kolejne godziny, w czasie których nadrabia materiał szkolny. Efektem zaistniałej sytuacji są sfrustrowani, przeciążeni rodzice, rozżaleni, wyczerpani uczniowie oraz zdeprecjonowani, pozbawieni autorytetu nauczyciele. Na frustracje rodzicielskie, wynikające $\mathrm{z}$ „przeniesienia szkoły do domu” oraz realizacji zadań nauczycielskich przez rodziców, nakłada się coraz większa niechęć do instytucji, jaką jest szkoła, ale także do samych nauczycieli. Zaistniała sytuacja procentuje negatywnymi opiniami na temat nauczycieli, coraz głośniej artykułowanymi $\mathrm{w}$ domach rodzinnych, co $\mathrm{z}$ kolei daje uczniom przyzwolenie do demonstrowania niestosownych zachowań w postaci pyskówek i aroganckich komentarzy wobec nauczycieli, a czasami nawet bezpośredniej deprecjacji zawodu nauczyciela na forum klasy. Niestety, tylko nieliczni nauczyciele radzą sobie z takimi zachowaniami, większość z nich przywykła do opisywanej sytuacji i za cenę "świętego spokoju” zdaje się nie zauważać przywołanych zachowań. Wszyscy odgrywają swoje role, nie bacząc na koszty. Jednym z efektów tej gry jest, w moim przekonaniu, „nowa jakość” edukacji wyższej.

Zmiany $\mathrm{w}$ polskim szkolnictwie wyższym zapoczątkowane $\mathrm{w}$ okresie transformacji ustrojowej spowodowały, że Polska przeszła z modelu mało dostępnego, elitarnego szkolnictwa wyższego do modelu bardziej egalitarnego. Konsekwencje tych zmian należy postrzegać zarówno w kategoriach pozytywnych, jak i negatywnych. Wśród pozytywnych na pewno należy wskazać wzrost skolaryzacji społeczeństwa oraz szeroko rozumiany rozwój szkolnictwa wyższego (powstawanie nowych kierunków, nowych uczelni, rozwój już istniejących), z kolei wśród negatywnych najczęściej podnosi się te, które związane są z jakością kształcenia oraz nowymi standardami studiowania. Jak piszą Małgorzata Chrupała-Pniak i Agata E. Chudzicka-Czupała:

dynamiczne zmiany zachodzące w otoczeniu uniwersytetu i w samym uniwersytecie spowodowały pewien swoisty chaos wartości i postaw, zarówno naszych wychowanków, studentów, jak i nas samych ${ }^{16}$.

Cytowane autorki, powołując się na Tadeusza Sławka ${ }^{17}$, wskazują kierunek zmian współczesnego uniwersytetu, podkreślają, iż wcześniej uniwersytet promował zachowania nieufne wobec systemu, prowokował wolną myśl i inicjował niezależne działania. Obecnie, uniwersytet częściej utożsamiany jest z rynkiem szkół wyższych oraz rynkiem pracy, budowaniem lojalności klienta

${ }^{16}$ M. Chrupała-Pniak, A. Chudzicka-Czupała, Poza ciemna strona, czyli jak odkryć i rozumieć trudne sytuacje w pracy ze studentami, [w:] Uczyć z pasją: wskazówki dla nauczycieli akademickich, red. B. Kożusznik, J. Polak, Katowice 2014, s. 319.

17 T. Sławek, Antygona w świecie korporacji. Rozważania o uniwersytecie i czasach obecnych, Katowice 2002. 
i kreowaniem wizerunku, co, niestety, przekłada się na nowe funkcjonalności uniwersytetu, czyli koncentrację na biurokracji oraz zaspokajaniu potencjalnych klientów - studentów i pracodawców"18. Wyraźnie widać, iż na uczelniach coraz większy nacisk kładzie się na pragmatyzm i komercjalizację ukierunkowane na realizację oczekiwań klientów - studentów. To, co było istotą, rdzeniem uniwersytetów jeszcze kilkanaście lat temu, czyli wiedza, sam proces jej zdobywania, dochodzenia do prawdy, staje się dzisiaj jedynie narzędziem, swego rodzaju instrumentem wykorzystywanym do realizacji innych jednostkowych celów. I tutaj pojawia się pytanie o nowe role wykładowców, nauczycieli akademickich: czy powinni bronić „uniwersyteckości”, odcinać się od nowych funkcjonalności uczelni i skupić wyłącznie na nauce, przekazywaniu wiedzy? Czy też raczej podążać za wyzwaniami współczesności i oczekiwaniami „klientów-studentów”? Przyznaję, że jako osoba związana ze środowiskiem akademickim odczuwam swego rodzaju dysonans w tym obszarze; $\mathrm{z}$ jednej strony mam świadomość potrzeb studentów, którzy chcą (przynajmniej w deklaracjach) jak najlepiej przygotować się do przyszłej pracy, oczekując jak najwięcej praktyki (co wskazywałoby na dużą świadomość młodych osób oraz proaktywne postawy wobec przyszłości edukacyjno-zawodowej), a z drugiej strony przekonanie, iż prezentowane przez studentów postawy są demonstracją ignorancji wobec wiedzy, brakiem zaufania do instytucji, jaką jest uniwersytet i podważaniem programów studiowania oraz metod proponowanych przez wykładowców. Nowe, do niedawna niespotykane zachowania studenckie wymuszają nowe role akademików. Role te wiążą się nie tylko ze zmianą sposobu uczenia, z metodyką, co jest pozytywnym zjawiskiem i pewnie bardziej znakiem czasu aniżeli konsekwencją zachowań studenckich, ale przede wszystkim nowymi zasadami/zależnościami/powinnościami pojawiającymi się na linii student - wykładowca/nauczyciel akademicki. Niestety, obserwowane zmiany budzą pewne obawy, w szczególności fakt, iż praca dydaktyczna pracowników uniwersyteckich utożsamiana jest głównie z przekazywaniem informacji, dawaniem gotowych rozwiązań. Brakuje przestrzeni do merytorycznej dyskusji, wspólnego analizowania problemów, stawiania hipotez. Paradoks tej sytuacji polega na tym, że w czasach, kiedy informacje są ogólnodostępne i nie trzeba nawet wychodzić $\mathrm{z}$ domu, żeby je zdobyć, nasza rola sprowadza się bardzo często do transformatorów tych informacji albo roli opiekunów grup studenckich, w trosce o studenta i jego poczucie bycia "dopieszczonym”. W tym miejscu chcę bardzo mocno podkreślić, iż nie mam żadnych wątpliwości co do tego, że uczelnie powinny stosować/proponować nowe rozwiązania, szczególnie $\mathrm{w}$ zakresie uelastycznienia i modernizacji procesu studiowania oraz form kształcenia studentów, co oczywiście wymaga dużego zaangażowania i otwar-

${ }^{18}$ M. Chrupała-Pniak, A. Chudzicka-Czupała, Poza ciemna strona, s. 319. 
tości na zmianę również ze strony nauczycieli akademickich, jednak wątpliwości budzi fakt związany z tak zwaną kulturą studiowania. Wracając do analogii kompetencyjnego rollercoastera, chciałam zauważyć, iż po raz kolejny mamy do czynienia z „wywrotką kompetencyjną”. Mam wrażenie, iż jako nauczyciele akademiccy podejmując obowiązki opiekunów grup studentów, coraz częściej realizujemy zadania „wychowawcze”, które powinny zostać zrealizowane w szkole i domu rodzinnym. Jako opiekunowie dostajemy coraz dłuższe instrukcje postępowania ze studentami, listę zadań, które musimy zrealizować. $\mathrm{Z}$ jednej strony mamy przed sobą dorosłe, decyzyjne osoby, z własnymi potrzebami i oczekiwaniami, a z drugiej „instrukcję prowadzenia za rękę”, jakby studenci wymagali specjalnego wsparcia. Zastanawia mnie fakt, czemu służą tego typu działania adresowane do osób, które doskonale radzą sobie w zglobalizowanym, cyfrowym świecie. Czy rolą uczelni, a dokładniej nauczycieli akademickich powinno być maksymalne upraszczanie wszystkiego, dawanie już na wstępie informacji „o nic się nie martw, my się wszystkim zajmiemy"? Czy warunki, które zapewniają studentom polskie uczelnie wzmacniają podmiotowość, sprawczość, samodzielność młodych dorosłych i tym samym przygotowują do roli odpowiedzialnego pracownika? Czy raczej utwierdzają w przekonaniu, że zawsze znajdzie się przed nimi jakaś „kosiarka”, która wyrówna teren, który będą przemierzać? Niestety, doświadczenia w pracy z młodzieżą pokazują, że działania głęboko „wspomagające” demotywują młodych dorosłych do podejmowania jakichkolwiek wysiłków i często stają się usprawiedliwieniem dla niekompetencji i aroganckich, niekulturalnych zachowań. Zdaję sobie sprawę, iż nie wszyscy muszą się zgadzać z prezentowanym punktem widzenia i że nie dotyczy on wszystkich studentów, co nie zmienia faktu, iż nowoczesne podejście do studentów, traktowanie ich przede wszystkim jako odbiorców usług edukacyjnych, czy wręcz klientów (czego potwierdzeniem jest chociażby umowa między studentem a uniwersytetem, jaką do niedawna podpisywali podejmując studia) zaburza pewien ład, wymuszający wzajemne poszanowanie w układzie student-nauczyciel akademicki. Jeśli chcemy, aby przyszłe elity przestrzegały zasady ładu społecznego, musimy przestrzeganie tych reguł od nich egzekwować, nie możemy wyrażać zgody na brak szacunku do drugiego człowieka, na bylejakość i brak kultury. Przechadzając się korytarzami zacnych uczelni, coraz częściej słyszymy niewybredne sformułowania, które bynajmniej nie świadczą o wysokim poziomie kultury osobistej studentów, ani o ich dojrzałości. Jednak najgorsze jest to, że stały się one normą, jesteśmy obojętni, zakłopotani, nikt nie śmie zwrócić uwagi „państwu studentom” - przecież są dorośli, nie podlegają już procesom wychowawczym, powinni wynieść to z domu, ewentualnie ze szkoły. Z kolei, szkolne korytarze aż kipią od wulgaryzmów, obśmiewania i poniżania innych, co w przyszłości przenosi się w nieco złagodzonej formie na dziedzińce uczelniane. Odnoszę wrażenie, 
iż problem braku kultury wśród studentów jest jednak problemem, którego oni w ogóle nie dostrzegają. Kiedyś student spóźniający się na zajęcia, nieobecny na seminariach, używający niewybrednego słownictwa, bądź niestosownie ubrany, w sytuacji kiedy zwrócono mu uwagę, czuł zażenowanie i wstyd. Obecnie te uczucia częściej towarzyszą wykładowcom. Niejednokrotnie sama będąc w takiej sytuacji, zastanawiam się, jak zareagować i czy reagować. Wiedziałabym co zrobić jako rodzic, ale nie jako nauczyciel akademicki. „Instrukcja obsługi studenta" nie przewiduje reakcji/interwencji w tego typu sytuacjach, a efekty kształcenia nie zakładają tego typu oddziaływań. Być może zaprezentowane refleksje zostaną odebrane jako brak profesjonalizmu z mojej strony albo, parafrazując M. Malewskiego, jako obawę przed

...nadchodzącym zmierzchem obowiązującego dotąd modelu naukowości, któremu towarzyszy zwykle dominujące poczucie pogłębiającej się profesjonalnej nieadekwatności i lęk przed utratą wysokiej dotąd pozycji w akademickim środowisku' ${ }^{19}$.

Pytanie tylko, czy uniwersytet, ze swoimi tradycjami jest miejscem uczenia podstawowych zasad kultury osobistej, czy ma jednak trochę bardziej ambitne cele?

Oczywiście, jak wspomniałam już wcześniej, nakreślony obraz zachowań studenckich nie dotyczy całej społeczności akademickiej i pewnie jest krzywdzący względem niektórych studentów, jednak mam nieodparte wrażenie, że problem roszczeniowości i braku kultury wśród studentów ma charakter rozwojowy. Zaistniała sytuacja jest konsekwencją nie tylko przemian cywilizacyjnych, procesów rozwojowych, związanych między innymi z tak zwanym odraczaniem dorosłości, ale przede wszystkim przemian $\mathrm{w}$ realizowanych modelach rodzicielstwa. Nadmierna koncentracja na dziecku, ciągła atencja, realizacja i natychmiastowe zaspokajanie potrzeb, wyręczanie dzieci i młodzieży w rozwiązywaniu ich problemów determinuje zachowania egoistyczne, a te utrudniają funkcjonowanie w zróżnicowanych strukturach, przestrzeniach i implikują nowy układ sił oraz rozkład kompetencji.

Analizując nowy porządek $\mathrm{w}$ tytułowych przestrzeniach życiowych, warto poświęcić trochę uwagi również środowiskom pracowniczym, które często postrzega się jako te, które powinny korzystać z kapitału wypracowanego przez takie instytucje, jak szkoła, uczelnia, czy rodzina, tymczasem współcześnie częściej pełnią rolę „zespołów wyrównujących braki kompetencyjne" młodych pracowników. Dynamiczne zmiany zachodzące na rynku pracy na przestrzeni ostatnich lat powodują, iż również środowisko pracy jest obszarem, w którym możemy zaobserwować nowy układ ról i relacji pomiędzy podmiotami w nim funkcjonującymi. Rosnąca liczba miejsc pracy,

${ }^{19}$ M. Malewski, Od nauczania do uczenia się, s. 191. 
otwarcie rynku na pracowników zza granicy powoduje, iż pracodawcy stają przed nowymi wyzwaniami. Kandydat świadomy sytuacji, nie tylko ubiega się o pracę, konkretne stanowisko, ale otwarcie artykułuje swoje oczekiwania i przynosi ze sobą „listę życzeń" do spełnienia. Obserwujemy nowy rozkład sił w relacji pracodawca - pracownik. Eksperci twierdzą, iż

wcześniej kandydat ubiegał się o stanowisko u pracodawcy, teraz oba podmioty są równorzędnymi partnerami, podejmującymi się wymiany dóbr i negocjującymi warunki tej wymiany ${ }^{20}$.

O ile jestem skłonna zgodzić się z faktem, iż spora grupa pracodawców w erze rynku pracodawcy nadużywała swojej pozycji, stawiając względem kandydatów wygórowane oczekiwania, oferując przy tym nieadekwatne wynagrodzenie, o tyle trudno zgodzić się ze stwierdzeniem, iż obecnie mamy na rynku pracy partnerstwo $\mathrm{w}$ relacji pracownik-pracodawca. Warto przypomnieć, iż partnerstwo, w odniesieniu do jakiejkolwiek sytuacji, powinno kierować się zasadami zbliżonymi do tych stosowanych w negocjacjach określanych kategoriami wygrana - wygrana (win win), czyli takich, w których obie strony dążą do uzyskania korzyści oraz satysfakcjonującego dla wszystkich rozwiązania, wzajemnego szacunku. Obserwując sytuację na rynku pracy, odnoszę wrażenie, że dalecy jesteśmy od takich rozwiązań. W moim odczuciu, rynek pracy zbyt często jest przestrzenią, w której dominują strategie typu wygrana - przegrana, zmieniają się tyko zwycięzcy i przegrani. Biorąc pod uwagę aktualną sytuację na rynku pracy, nietrudno zauważyć, iż w roli przegranych częściej występują pracodawcy, co wynika między innymi z rynku pracownika. Taki układ sił naturalnie wzmacnia pozycję strony uprzywilejowanej. Warto jednak zastanowić się nad tym, czy zmiany na rynku pracy powinny automatycznie uruchamiać nowe, zmienione o 180 stopni postawy pracodawców względem pracowników, szczególnie tych prezentujących najmłodsze pokolenia? Debata publiczna koncentrująca się na relacjach pracodawca - pracownik, w kontekście przejścia od rynku pracodawcy do rynku pracownika, postrzega te zmiany jako pozytywne, jako zjawisko, "przywołujące pracodawców do porządku”. Brakuje jednak myślenia kategoriami szerszymi, stawiającymi pytania o cel pracy: czy mają to być wyłącznie cele jednokierunkowe, skoncentrowane na zaspokajaniu potrzeb pracownika bądź pracodawcy w zależności od sytuacji na rynku pracy, czy raczej cele wielokierunkowe, uwzględniające rozwój pracowników oraz pracodawców i budowanie relacji pracowniczych w miejscu pracy? Poszukując odpowiedzi na to pytanie, warto spojrzeć na środowisko pracy jako przestrzeń nowych

${ }^{20}$ Jakość procesów rekrutacji. Raport z badania, https://www.aplikuj.pl/userfiles/_CMS_/ jakosc-procesow-rekrutacji-\%E2\%80\%93-raport-aplikuj.pl.pdf [data dostępu: 13.06.2019]. 
ról i zadań, do realizacji których obligowani są współcześni pracodawcy. Nie mam tutaj na myśli zadań związanych z nowoczesnymi technologiami, choć na pewno są one sporym wyzwaniem dla pracodawców, jednak biorąc pod uwagę czas, jaki poświęca się im w debacie publicznej, wydają się być „zaopiekowane". Istotniejsze wydają się takie funkcjonalności pracodawców, jak: bycie mentorem, architektem mostów międzypokoleniowych, autorytetem, osobą motywującą i rozwijającą kompetencje miękkie pracowników, nauczycielem kompetencji twardych i wreszcie osobą odpowiedzialną za budowanie relacji w miejscu pracy. Paradoks sytuacji, w której znajduje się pracodawca polega na tym, iż przestrzeń, w której funkcjonuje, którą tworzy, powinna być miejscem, w którym pracownik wykorzystuje potencjał, który do tej pory rozwinął i zgromadził, tymczasem częściej staje się miejscem, gdzie pracodawca mierzy się z zadaniami, które powinny zostać wypracowane w trakcie edukacji szkolnej bądź akademickiej. Pracodawca pomimo wysiłków instytucji edukacyjnych, ukierunkowanych na realizację pragmatycznych oczekiwań uczniów i studentów, coraz częściej wchodzi w rolę „organizatora kursów wyrównawczych z braków kompetencyjnych", szczególnie w obszarze kompetencji miękkich, transferowalnych. Obserwujemy również pewien paradoks edukacyjny - szkoła, studia kształcą uczniów i studentów do pracy, dla pracodawców, inwestują w konkretne umiejętności przydatne na rynku pracy (bardziej twarde, zawodowe), tymczasem pracodawcy bardziej niż kiedykolwiek potrzebują w pracowniku człowieka, myślącej, krytycznej również wobec siebie istoty, otwartej na innych i na świat. Od dawna mówimy o miejscu pracy jako o organizacji uczącej się, tymczasem współczesne firmy coraz częściej stają się szkołami wyrównującymi braki w zakresie „kompetencji dorosłości", rozwijając u swoich pracowników odpowiedzialność, decyzyjność, komunikatywność, samodzielność i tym podobne. Współcześni pracodawcy, mając na uwadze długoterminową perspektywę rynku pracownika, bez większego oporu wchodzą w rolę nauczycieli wyrównujących braki wyniesione $z$ wcześniejszych etapów edukacyjnych i dostosowują się do nowych trendów rekrutacyjnych. Jednak problemy związane z pracownikami, szczególnie najmłodszymi, nie wynikają tylko z ich niekompetencji, mają szersze podłoże - związane są z poszukiwaniem sensu pracy oraz potrzebą przynależności do danej struktury. Niestety, domeną współczesności jest promowanie tymczasowości, braku przynależności do różnych struktur, środowisk, również pracowniczych, co odbiera szansę na zakorzenienie się, utożsamienie się z danym środowiskiem, miejscem i budowaniem jakichkolwiek relacji. Wydaje się, iż właśnie z tego powodu współcześni pracodawcy powinni zacząć bardziej dbać o pozytywne relacje pracownicze i budowanie poczucia przynależności pracowników do zespołu, nie tylko poprzez dostosowywanie się do stawianych przez nich wymagań, ślepe podążanie za 
nowymi "eventowymi” trendami rekrutacyjnymi i sprowadzaniem wszystkiego do gry czy zabawy, ale poprzez stwarzanie warunków do tego, aby młodzi pracownicy mieli szansę nie tylko „brać, ale również dawać” coś od siebie i wywiązywać się z poczynionych zobowiązań.

Nowe zadania, realizowane przez pracodawców w miejscach pracy, po raz kolejny podkreślają zmiany w obszarze kompetencji, czy podstawowych funkcji tytułowych przestrzeni: rodzina zamiast wychowywać, rozwijać i podtrzymywać więzi oraz relacje, koncentruje się na realizacji „projektu dziecko" oraz realizacji programu szkolnego; szkoła zamiast rozwijać kompetencje wykonawcze/społeczne u uczniów, robi wszystko, żeby uczeń o nich zapomniał, a studia zamiast uczyć krytycznego myślenia, analizowania i rozwiązywania problemów, poszerzania horyzontów coraz częściej koncentrują się na kompetencjach stricte zawodowych, które często po ukończeniu studiów są już nieaktualne, z kolei pracodawca zamiast rozwijać specjalistów, próbuje odbudować kompetencje typu kreatywność, samodzielność, odpowiedzialność, które powinny być rozwinięte $\mathrm{w}$ domu rodzinnym i szkole podstawowej.

Obserwowane zmiany wydają się szczególnie interesujące w kontekście prognoz dotyczących przyszłości. Raport „Future of Skills. Employment in 2030" wskazuje, że w nadchodzących latach liczyć się będą cztery główne kategorie umiejętności: interpersonalne, społeczne, systemowe oraz poznaw$\mathrm{cze}^{21}$. Z kolei na rynku pracy potrzebni będą przede wszystkim ludzie chcący się uczyć oraz potrafiący uczyć innych. W cenie będą także umiejętności logicznego myślenia, dedukcji, współdziałania, kompleksowego rozwiązywania problemów, oceny sytuacji oraz podejmowania decyzji. Eksperci z Pearson zwracają także uwagę na umiejętność określaną jako „social perspectiveness", czyli zdolność dostrzegania innych ludzi i ich reakcji oraz zrozumienia, z czego one wynikają; równie ważna będzie zdolność autorefleksji ${ }^{22}$. Wyraźnie kształtują się także trendy $\mathrm{w}$ polityce zarządzania zasobami ludzkimi. Prowadzenie firmy w dobie gospodarki 4.0 będzie wymagało od pracodawcy zmiany podejścia na takie, w którym to pracownik stanie się centrum strategii biznesowej. Jak wskazują wyniki raportu Human Capital Trends 201923, w pracowniku należy przede wszystkim widzieć człowieka. Proponowane zmiany wydają się być dobrą propozycją, wzmacniającą znaczenie czynnika ludzkiego $\mathrm{w}$ organizacji, dostrzegającą $\mathrm{w}$ nim nie tylko podmiot generujący

${ }^{21}$ A. Jadczak, Prognozy dla rynku pracy w 2030 roku, https:/ /itwiz.pl/prognozy-dla-rynku-pracy-2030-roku/ [data dostępu:13.06.2019].

${ }^{22}$ Tamże.

${ }^{23}$ Leading the social enterprise: Reinvent with a human focus, https://www2.deloitte.com/content/dam/insights/us/articles/5136_HC-Trends-2019/DI_HC-Trends-2019.pdf [data dostępu: 13.06.2019]. 
zyski i nośnik konkretnych, użytecznych kompetencji, ale przede wszystkim osobę. Trzeba jednak uważać, żeby nowy trend nie stał się dla młodych pokoleń zachętą do nadużywania swojej pozycji.

Biorąc pod uwagę obserwowane zmiany, jeszcze bardziej niepokoi nowy rozkład ról i kompetencji we wcześniej analizowanych przestrzeniach, w których większość wysiłków związanych z rozwojem młodych osób koncentruje się na osiągnięciach edukacyjnych, jako centralnej inwestycji w przygotowaniu do dorosłości, zamiast na rozwoju społeczno-emocjonalnym. Młodzi dorośli, często zaprogramowani przez rodziców i szkołę na realizację projektu BRAWO JA, w którym umiejętności i sprawności, na których realizacji się koncentrują, są szybko weryfikowane, nie mają czasu na rozwijanie kompetencji trudniej weryfikowalnych, wymagających większego zaangażowania i głębszej refleksji. Postawy prezentowane przez młodych zachęcają ich do nadmiernej identyfikacji z rolami, które pełnią w różnych przestrzeniach, szczególnie tymi w życiu zawodowym, a tym samym zapominają o „byciu” kompetentnymi, profesjonalnymi dorosłymi. Wyraźnie obserwujemy odwrócony model "bycia", funkcjonowania i to nie tylko młodych dorosłych, ale dorosłych w ogóle. Współcześnie w pierwszej kolejności widzimy pracownika, fachowca, ucznia, studenta, postrzegamy ich przez pryzmat osiągnięć, dyplomów, ocen, pełnionych funkcji, a dopiero później dostrzegamy człowieka. Zapominamy o tym, że aby podejmować role, zarówno te związane z życiem osobistym i zawodowym, najpierw trzeba być człowiekiem ${ }^{24}$.

Analizując zaproponowane przestrzenie: rodzinę, edukację i pracę wyraźnie widać zachodzące $\mathrm{w}$ nich przemiany, widać również opór wobec niektórych z nich, niezadowolenie poszczególnych "aktorów” tych przestrzeni, a mimo to dostosowywanie się do tego co nowe, choć nie zawsze lepsze. Odnoszę wrażenie, iż jako społeczeństwo mamy ogromną skłonność do bezrefleksyjnego podążania za tym co nowe i przyjmowania tego pomimo pojawiających się obaw, kosztem własnych priorytetów i wartości. Zakładamy różowe okulary i udajemy, że nie dostrzegamy zagrożeń, widzimy tylko ryzykowne zyski zmian. Być może, jak twierdzi izraelski historyk Y.N. Harari:

w XXI wieku raczej nie można sobie pozwolić na stabilność. Jeśli ktoś próbuje się trzymać jakiejś stałej tożsamości, pracy lub światopoglądu, naraża się na to, że świat przemknie obok niego ze świstem, a on zostanie daleko w tyle. By zachować jakiekolwiek znaczenie - nie tylko ekonomiczne, ale przede wszystkim społeczne - człowiek będzie potrzebował umiejętności nieustannego uczenia się i szukania nowych pomysłów na siebie ${ }^{25}$.

${ }^{24}$ A. Wawrzonek, Młodzi dorośli i obszary ich (nie)kompetencji, [w:] Społeczne i podmiotowe uwarunkowania rozwoju młodzieży, red. A. Cybal-Michaska, M. Orłowska, W. Segiet, Dąbrowa Górnicza 2018, s. 47.

${ }^{25}$ Y.N. Harari 21 lekcji na XXI wiek, s. 338. 
I, aby przetrwać i rozwijać się w takim świecie, potrzebne będą niezwykła elastyczność, potężne rezerwy równowagi emocjonalnej ${ }^{26}$, a także mocno zapięte pasy na tytułowym rollercoasterze, który nie tylko będzie przyspieszał w najmniej oczekiwanym momencie, ale także zmieniał kierunek zmian i układ ról, które pełnimy. Odnoszę wrażenie, że spora część społeczeństwa bez entuzjazmu wsiada do tego rollercoastera, ale też niewiele robi, żeby z tej przejażdżki zrezygnować albo uczynić ją bardziej znośną. Zmiany, za którymi podążamy często stają się destrukcją, reformy stają się deformą, a sposób i motywy ich wprowadzania nie podlegają dyskusji. Niestety, często udajemy, że obawy związane z wprowadzaniem zmian nas nie dotyczą, nie mamy odwagi stawiania granic, szukania kompromisów w procesie technologizacji życia społecznego. Powody takiej postawy wynikają pewnie z obawy przed oceną (chociaż sami chętnie oceniamy innych), kwestionowaniem naszych przekonań, zarzutami braku elastyczności oraz zbyt tradycyjnym podejściem do życia. Kolejnym paradoksem współczesności staje się fakt, iż w dobie fascynacji nowoczesnymi technologiami, cyfryzacją bardziej niż kiedykolwiek zamiast być ocenianym potrzebujemy być docenionym przez drugiego człowieka. Jako społeczeństwo cierpimy na deficyt uznania, o czym pisze Axel Honneth w książce Walka o uznanie ${ }^{27}$. Współczesny świat pomimo promowania silnych, niezależnych jednostek, które wydają się być samowystarczalne i spełnione, generuje ogromne zapotrzebowanie na uznanie, pozytywną informację zwrotną, pewnego rodzaju uważność, związaną z obecnością drugiego człowieka i celebrowaniem drobnych, zwyczajnych rzeczy.

Dzieląc się swoimi spostrzeżeniami, żywię głęboką nadzieję, iż nie zostaną one odebrane jako manifest wobec zmian. Pragnę jedynie pokreślić, iż to, czego potrzebujemy jako społeczeństwo i jako jednostki, funkcjonujące w różnych przestrzeniach, to „wzmacnianie procesu podmiotowego zakorzenienia się we współczesnym świecie" ${ }^{28}$. Niestety, kultura egoizmu, zbyt duży nacisk na indywidualizm, kultywowanie "ja” zatraciło "my”, tymczasem człowiek nie potrafi żyć w próżni, potrzebuje relacyjności, wspólnotowości, zakotwiczenia i poczucia przynależności. To właśnie wskazane czynniki konstytuują człowieka i kształtują jego tożsamość. Dlatego nie można odseparowywać od siebie pełnionych ról i funkcji, sztywno trzymać się każdej z nich, trzeba je łączyć i nadawać im relacyjny charakter względem przestrzeni, w których żyjemy. Jak pisze Jasper Juul, wszyscy musimy wykraczać poza swoje role, żeby stać się po prostu ludźmi: nauczyciele poza rolę nauczyciela, rodzice poza rolę rodzica, a uczniowie poza rolę ucznia. Nie działa już autorytet zbu-

${ }^{26}$ Tamże, s. 339.

27 A. Honneth, Walka o uznanie. Moralna gramatyka konfliktów społecznych, Kraków 2012.

${ }_{28}$ M. Boni, Zakończenie - rekomendacje, [w:] Młodzi 2018, Warszawa 2019, s. 232, http:// mlodzi2018.pl/ [data dostępu: 12.07.2019]. 
dowany na odgrywaniu swojej roli. Każdy musi od podstaw budować swój osobisty autorytet ${ }^{29}$.

Podsumowując, za Y.N. Harari, chciałabym podkreślić, iż

poszukiwanie odpowiedzi na pytanie „Kim jestem?” w świecie, w którym życie rozpada się na kawałki, złożone z różnych ról i funkcji, które pełnimy w życiu, między którymi jest coraz mniej ciągłości, stanie się bardziej naglące i skomplikowane niż kiedykolwiek wcześniej3.

Dlatego szczególnie ważne wydaje mi się nadanie relacyjnego charakteru opisywanym przestrzeniom, co w moim odczuciu pozwoli odnaleźć osobom w nich funkcjonującym swoją tożsamość i wzmocni ich poczucie podmiotowości, przynależności i wspólnotowości. Trudno jednak wzmacniać podmiotowość człowieka, jeśli na różnych etapach jego rozwoju traktujemy go jako odrębne byty, wyspecjalizowane do realizacji krótkoterminowych zadań, generowanych w różnych przestrzeniach. Ważne jest dostrzeżenie potrzeby relacyjności pomiędzy tymi przestrzeniami, holistyczne podejście do rozwoju człowieka, z poszanowaniem każdej z tych przestrzeni. Nie będzie dobrego pracownika, jeśli wcześniej nie będzie dobrego ucznia i studenta. Nie będzie dobrego ucznia, jeśli ten nie będzie się uczył w dobrze zorganizowanej, przyjaznej szkole. Nie będzie myślących, samodzielnych, zdolnych do autorefleksji studentów, jeżeli nie damy im szansy na bycie samodzielnymi i samostanowiącymi o sobie jednostkami. Wreszcie, nie będzie „ludzkiego pracownika", jeśli odczłowieczymy go w toku edukacji, koncentrując się na kompetencjach twardych, nie dbając o więzi i relacje. Tylko dbałość o integralność rozwoju człowieka zapewni mu odpowiednie poczucie własnej wartości i pozwoli kształtować postawę zaufania do świata. Instrumentalne podejście do edukacji wyklucza dbałość o podstawowe wartości, które wydają się być fundamentem funkcjonowania w społeczeństwie. Godność, pokora, uczciwość, szacunek do siebie i innych, zaufanie, relacje, wreszcie troska o siebie i innych to kategorie, które częściej stają się konstruktem teoretycznym, tymczasem powinny pełnić rolę życiowych drogowskazów. Odchodząc od tych drogowskazów, coraz częściej, czasami nieświadomie, promujemy narcyzm, brak szczerości, pazerność, podejrzliwość, a te niczym chwasty rozprzestrzeniają się w naszym życiu. Niestety, wadliwy system edukacyjny, zaburzone relacje rodzinne, nowe wyzwania rynku pracy nie wyposażają w wiedzę, która pozwoliłaby dostrzec te chwasty. Brak rzetelnej wiedzy, szum informacyjny, któremu się poddajemy powoduje, że coraz częściej je pielęgnujemy i pozwalamy, by swoją ekspansywnością zakryły najistotniejsze

\footnotetext{
${ }^{29}$ J. Juul, Zamiast wychowania. O sile relacji z dzieckiem, Podkowa Leśna 2016, s. 77.

30 Y.N. Harari, 21 lekcji na XXI wiek, s. 337.
} 
wartości. Odbudowanie integralnej wizji człowieka wymaga współdziałania wielu osób oraz instytucji i powinno odbywać się na wielu płaszczyznach. Szkoła powinna koncentrować się nie tylko na kompetencjach poznawczych, ale przede wszystkim na wzmacnianiu podmiotowości uczniów i rozwijaniu kompetencji wykonawczych ${ }^{31}$. Zadaniem szkoły nie może być wyłącznie edukowanie, w rozumieniu przekazywania wiedzy oraz wyposażanie uczniów w pakiet sprawności przydatnych z punktu widzenia pracodawców, ale przede wszystkim wspomaganie ich rozwoju emocjonalnego i społecznego. Nie jest to możliwe bez współpracy z rodzicami i zmianą ich podejścia do wychowywania dzieci. Istotne wydaje się także zaprojektowanie zmian w obszarze edukacji wyższej, która powinna nie tylko realizować oczekiwania studentów i podążać za wymaganiami rynku pracy, ale przede wszystkim bronić fundamentalnych wartości uniwersyteckich. I wreszcie pracodawcy, którzy powinni dostrzegać walory młodych pokoleń, czerpać z ich potencjału, pozwalać zmieniać, ale jednocześnie pamiętać o tym, że są też inni, starsi tak samo ważni pracownicy, którzy też zasługują na uznanie i szacunek. Parafrazując słowa M. Boniego, właściwą drogą do przyszłości wydaje się być ta, która nie będzie polegała wyłącznie na dostosowywaniu się do „kogoś lub czegoś" (do dziecka, rodzica, studenta, roszczeniowego pracownika, do zmiany), ale dodatkowo na tworzeniu warunków, by to oni „dali coś z siebie” sobie i światu ${ }^{32}$.

\section{BIBLIOGRAFIA}

Acuff J., Zawodowo od nowa, Wydawnictwo samo sedno, Warszawa 2016.

Alvarez C., Prawa naturalne dziecka. Rewolucja w edukacji dla rodziców i pedagogów, Wydawnictwo CoJaNaTo, Warszawa 2017.

Boni M., Zakończenie - rekomendacje [w:] Raport Młodzi 2018, Warszawa 2019 na: http:// mlodzi2018.pl/files/raport14.pdf.

Chrupała-Pniak M., Chudzicka-Czupała A., Poza ciemna strona, czyli jak odkryć i rozumieć trudne sytuacje w pracy ze studentami, [w:] Uczyć z pasja: wskazówki dla nauczycieli akademickich, red. B. Kożusznik, J. Polak, Wydawnictwo Uniwersytetu Śląskiego, Katowice 2014.

Espinoza Ch., Milenialsi w pracy. 7 umiejętności, którzy powinni posiaść dwudziestokilkulatkowie, by móc pokonywać bariery w życiu i w pracy, Warszawa 2016.

Harari Y.N., 21 lekcji na XXI wiek, Wydawnictwo Literackie, Warszawa 2011.

Herbst M., Reformowanie edukacji [w:] Młodzi 2018, Warszawa 2019, na: http://mlodzi2018. $\mathrm{pl} /$ files/raport14.pdf

Honneth, A., Walka o uznanie. Moralna gramatyka konfliktów społecznych, Zakład Wydawniczy Nomos, Kraków 2012.

${ }^{31}$ C. Alvarez, Prawa naturalne dziecka. Rewolucja w edukacji dla rodziców i pedagogów, Warszawa 2017.

${ }^{32}$ M. Boni, Zakończenie-rekomendacje, [w:] Młodzi 2018, Warszawa 2019, s. 232. 
Honore C., Pod presją. Dajmy dzieciom święty spokój, Wydawnictwo Drzewo Babel, Warszawa 2008.

Jadczak A., Prognozy dla rynku pracy w 2030 roku, https:/ /itwiz.pl/prognozy-dla-rynku-pracy-2030-roku/Jakość procesów rekrutacji - raport na: https:/ / www.aplikuj.pl/userfiles/_CMS_/jakosc-procesow-rekrutacji-\%E2\%80\%93-raport-aplikuj.pl.pdf

Jurczyk-Romanowska E., Piwowarczyk M. (red.), Wychowanie w rodzinie tom XIII I/2016, Wspótczesna rodzina w kontekstach społecznych i kulturowych, Wydawnictwo Naukowe Uniwersytetu Wrocławskiego, Wrocław 2016

Juul J., Zamiast wychowania. O sile relacji $z$ dzieckiem, Wydawnictwo MiND, Podkowa Leśna 2016.

Lahey J., Nauczka, czyli jak przekuć porażkę w sukces. Wychowawcze putapki i sekrety, Buchmann, Warszawa 2016.

Leading the social enterprise: Reinvent with a human focus, https://www2.deloitte.com/content/dam/insights/us/articles/5136_HC-Trends-2019/DI_HC-Trends-2019.pdf

Malewski M., Od nauczania do uczenia się. O paradygmatycznej zmianie w andragogice, Wydawnictwo Naukowe DSW, Wrocław 2010.

Opozda D., Statość i zmienność stylu wychowania w rodzinie w teorii i praktyce edukacyjnej, [w:] Wspótczesna rodzina w kontekstach społecznych i kulturowych, Wychowanie w rodzinie, t. XIII, red. E. Jurczyk-Romanowska, M. Piwowarczyk, Wrocław 2016.

Prognozy dla rynku pracy 2030 na: https:/ /itwiz.pl/ prognozy-dla-rynku-pracy-2030-roku/ Raport HC Trends 2019, na: https:/ / www2.deloitte.com/content/dam/insights/us/articles/5136_HC-Trends-2019/DI_HC-Trends-2019.pdf

Raport Młodzi 2018, Warszawa 2019, na: http:/ / mlodzi2018.pl/files/raport14.pdf

Sławek T., Antygona w świecie korporacji. Rozważania o uniwersytecie i czasach obecnych, Wydawnictwo Uniwersytetu Śląskiego, Katowice 2002.

Solarczyk-Ambrozik E., Transformacja pracy i zatrudnienia a kariera zawodowa. Perspektywa jednostkowa i organizacyjna, [w:] Uczenie się przez całe życie. Rozwój - kariera - praca, red. E. Solarczyk-Ambrozik, M. Barańska M., Wydawnictwo Naukowe UAM, Poznań 2018.

Społeczne i podmiotowe uwarunkowania rozwoju młodzieży, red. A. Cybal-Michaska, M. Orłowska, W. Segiet, Wydawnictwo Naukowe Akademii WSB, Dąbrowa Górnicza 2018.

Ślusarczyk A., Helikopterowi rodzice to już przeszłość. Nadchodza rodzice kosiarki. Poznaj nowy trend $w$ rodzicielstwie, https://www.babyboom.pl/uczen/wychowanie/helikopterowi-rodzice-to-juz-przeszlosc-nadchodza-rodzice-kosiarki-poznaj-kolejny-trend-w-rodzicielstwie

Uczenie się przez całe życie. Rozwój - kariera - praca, red. E. Solarczyk-Ambrozik, M. Barańska M., Wydawnictwo Naukowe UAM, Poznań 2018.

Uczyć z pasją: wskazówki dla nauczycieli akademickich, red. B. Kożusznik, J. Polak, Wydawnictwo Uniwersytetu Śląskiego, Katowice 2014.

Wawrzonek A., Młodzi dorośli i obszary ich (nie)kompetencji, [w:] Społeczne i podmiotowe uwarunkowania rozwoju młodzieży, red. A. Cybal-Michaska, M. Orłowska, W. Segiet, Wydawnictwo Naukowe Akademii WSB, Dąbrowa Górnicza 2018.

Wawrzonek, A., Sukces i jego implikacje dla ksztattowania tożsamości młodego człowieka, [w:] Uczenie się przez całe życie. Rozwój - kariera - praca, red. E. Solarczyk-Ambrozik, M. Barańska, Wydawnictwo Naukowe UAM, Poznań 2018.

Żylińska M., Neurodydaktyka. Nauczanie i uczenie się przyjazne mózgowi, Wydawnictwo Naukowe UMK, Torun 2013. 